\title{
Kinetic Study on Degradation of Micro-organics by Different UV-based advanced oxidation processes in EfOM Matrix
}

\section{Donghai Yuan}

Beijing University of Civil Engineering and Architecture

\section{Guangyu Liu}

Beijing University of Civil Engineering and Architecture

Fei Qi

Beijing Forestry University

Jinggang Wang

Beijing University of Chemical Technology

Yingying Kou ( $\nabla$ kouyy@bucea.edu.cn )

Beijing University of Civil Engineering and Architecture

\section{Yanqi Cui}

Beijing University of Civil Engineering and Architecture

\section{Minghui Bai}

Beijing University of Civil Engineering and Architecture

\section{Xinyu Li}

Beijing University of Civil Engineering and Architecture

\section{Research Article}

Keywords: Effluent organic matter (EfOM), advanced oxidation processes (AOPs), second-order reaction rate constants, sulfate radical, hydroxyl radical

Posted Date: December 6th, 2021

DOl: https://doi.org/10.21203/rs.3.rs-719769/v1

License: (c) (i) This work is licensed under a Creative Commons Attribution 4.0 International License. Read Full License

Version of Record: A version of this preprint was published at Environmental Science and Pollution Research on February 10th, 2022. See the published version at https://doi.org/10.1007/s11356-02219087-0. 



\title{
1 Kinetic Study on Degradation of Micro-organics by Different UV- 2 based advanced oxidation processes in EfOM Matrix
}

3 Donghai Yuan ${ }^{\mathrm{a}}$, Guangyu Liu ${ }^{\mathrm{a}}$, Fei Qi ${ }^{\mathrm{b}}$, Jinggang Wang ${ }^{\mathrm{c}}$, Yingying Kou ${ }^{\mathrm{a},{ }^{*},}$, Yanqi Cui ${ }^{\mathrm{a}}$, Minghui Bai ${ }^{\mathrm{a}}$,

4 Xinyu $\mathrm{Li}^{\mathrm{a}}$

5 a Key Laboratory of Urban Stormwater System and Water Environment, Ministry of Education,

6 Beijing University of Civil Engineering and Architecture, Beijing 100044, China

$7 \quad$ b Beijing Key Lab for Source Control Technology of Water Pollution, College of Environmental

$8 \quad$ Science and Engineering, Beijing Forestry University, Beijing, 100083, PR China

9 c College of Chemical Engineering, Beijing University of Chemical Technology, Beijing, 100029,

$10 \quad$ PR China

\begin{abstract}
:
Effluent Organic Matter (EfOM) contains a large number of substances that are harmful to both the environment and human health. To avoid the negative effects of organic matter in EfOM, advanced treatment of organic matter is an urgent task. Four typical oxidants $\left(\mathrm{H}_{2} \mathrm{O}_{2}, \mathrm{PS}, \mathrm{PMS}, \mathrm{NaClO}\right)$ and UVcombined treatments were used to treat micro-contaminants in the presence or absence of effluent organic matter (EfOM), because the active radical species produced in these UV-AOPs are highly reactive with organic contaminants. However, the removal efficiency of trace contaminants was greatly affected by the presence of EfOM. The degradation kinetics of two representative micro-contaminants (benzoic acid (BA) and para-chlorobenzoic acid(p-CBA)) was significantly reduced in the presence of EfOM, compared to the degradation kinetics in its absence. Using the method of competitive kinetics, with BA, $p$-CBA and 1,4-dimethoxybenzene (DMOB) as probes, the radicals $\left(\mathrm{HO}, \mathrm{SO}_{4}^{-{ }^{-}}, \mathrm{ClO}\right)$ proved to be the key to reaction species in advanced oxidation processes. UV irradiation on EfOM was not primarily responsible for the degradation of micro-contaminants. The second-order rate constants of the EfOM with radicals were determined to be $(5.027 \pm 0.643) \times 10^{2}\left(\mathrm{SO}_{4}^{--}\right),(3.192 \pm 0.153) \times 10^{4}\left(\mathrm{HO}^{\prime}\right)$ and $1.35 \times 10^{6}$ $(\mathrm{ClO})(\mathrm{mg}-\mathrm{C} / \mathrm{L})^{-1} \cdot \mathrm{s}^{-1}$. In addition, this study evaluated the production of three radicals based on the concept of $R_{c t}$, which can better analyze its reaction mechanism.
\end{abstract}

Key words: Effluent organic matter (EfOM); advanced oxidation processes (AOPs); second-order reaction rate constants; sulfate radical; hydroxyl radical 


\section{Introduction}

Urban sewage contains a large amount of organic matter of various and complex types. Although more than $90 \%$ of this organic matter can be effectively removed with conventional biological treatment, some refractory organic residue inevitably remains. These refractory dissolved organic substances remaining in sewage after primary and secondary biochemical treatment are collectively referred to as Effluent Organic Matter (EfOM).(Vigneswaran, 2006) While the concentration of emerging contaminants (ECs) in EfOM is extremely low in the environment,(Rosal et al., 2010) their high stability in wastewater makes them difficult to degrade with conventional biological treatment. (Taoufik et al., 2021) Conventional wastewater treatment processes including coagulation, sedimentation, filtration, and disinfection — can remove only a limited amount of EfOM, and sometimes highly toxic intermediate products are produced during treatment. Advanced Oxidation Process (AOPs) is a new type of highefficiency pollutant control technology developed in the 1980s.(Hisaindee et al., 2013) Because AOP has strong oxidizing ability and low selectivity to pollutants, and can remove trace amounts of harmful chemicals and refractory organics, it has been widely used in the treatment of contaminated groundwater, especially for the removal of some special trace pollutants in water. With the development of these advanced oxidation processes, in addition to the initial application of $\mathrm{OH}$, other highly reactive free radicals (such as $\mathrm{SO}_{4}^{--}, \mathrm{O}_{2}^{-}, \mathrm{Cl}$, etc.) can undergo electron transfer, or hydrogen addition or substitution, to react with refractory organic matter,(Khan and Adewuyi, 2010) thereby causing chemical bond breakage of the organic matter. It is even possible to directly mineralize the organic matter into carbon dioxide and water.

$\mathrm{UV} / \mathrm{H}_{2} \mathrm{O}_{2}$ is a conventional advanced oxidation process (AOP), based on the production of a hydroxyl radical $(\mathrm{HO})(\mathrm{E} 0=2.8 \mathrm{~V})$ via $\mathrm{UV} / \mathrm{H}_{2} \mathrm{O}_{2}$. The major water constituents known to scavenge $\mathrm{HO}$ are EfOM and inorganic species such as carbonate, bicarbonate, nitrite, and bromide ions.(Keen et al., 2014; Wols and Hofman-Caris, 2012) HO water matrix demand is commonly calculated based on measured concentrations of these compounds and the respective second-order rate constants (k.он., , M${ }^{1} \mathrm{~S}^{-1}$ ) for their reaction with $\mathrm{HO}$. The second-order rate constants for the reaction between $\mathrm{HO}$ and EfOM have been reported as 1.0-4.5×10 $\mathrm{MC}^{-1} \mathrm{~s}^{-1}$ (And and Fulkersonbrekken $\dagger$, 1998; Donham et al., 2014; Reisz et al., 2003), and these vary depend on the origin, characteristics, and composition of the EfOM.

An advanced oxidation process based on $\mathrm{SO}_{4}^{--}(\mathrm{E} 0=2.6 \mathrm{~V})$ could be applied as an alternative to those based on a hydroxyl radical (HO) for the remediation of organic pollutants in surface water, groundwater or wastewater.(Hori et al., 2005; Yang et al., 2014) $\mathrm{SO}_{4}{ }^{--}$is generated via the activation of peroxymonosulfate $\left(\mathrm{HSO}_{5}^{-}, \mathrm{PMS}\right)$ or persulfate $\left(\mathrm{S}_{2} \mathrm{O}_{8}{ }^{2-}, \mathrm{PS}\right)$ by UV, heat or transition metals.(Matta et al., 2011; Zhou et al., 2013)'(Milh et al., 2021) UV/persulfate possesses several advantages, including stability of the precursors (PMS or PS), ease of storage and transportation, high water solubility, versatile activation strategies and a wide operating pH range.(And and Dionysiou, 2004; Das, 2017), (Giannakis et al., 2021)

$\mathrm{UV} / \mathrm{Cl}$ is an emerging $\mathrm{AOP}$ alternative to the $\mathrm{UV} / \mathrm{H}_{2} \mathrm{O}_{2}$ process, as it produces $\mathrm{HO}$ and reactive chlorine species (RCS). The quantum yields of $\mathrm{HOCl}$ and $\mathrm{OCl}^{-}$by $\mathrm{UV}$ photolysis and their absorptivity are reported to be higher than those of $\mathrm{H}_{2} \mathrm{O}_{2}$. (Feng et al., 2007; Watts and Linden, 2007) Compared to $\mathrm{HO}$, RCS such as $\mathrm{Cl}^{\prime}, \mathrm{Cl}_{2}{ }^{-1}$ and $\mathrm{ClO}$ are powerful oxidants, with oxidation potentials of $2.47 \mathrm{~V}, 2.0 \mathrm{~V}$ and 1.5-1.8 V, respectively.(Alfassi et al., 1988; Beitz et al., 1998)

Previous studies have demonstrated the feasibility of adopting advanced oxidation processes to treat micro pollutants.(Cong et al., 2015)'(He et al., 2020) However, data on this topic are still scarce, 
especially for UV/oxidant methods for municipal wastewater treatment. In the present work, benzoic acid (BA), para-chlorobenzoic acid ( $p$-CBA) and 1,4-dimethoxybenzene (DMOB) were chosen as model compounds to investigate the degradation of micro pollutants in $\mathrm{UV} / \mathrm{H}_{2} \mathrm{O}_{2}, \mathrm{UV} / \mathrm{PS}, \mathrm{UV} / \mathrm{PMS}$ and $\mathrm{UV} / \mathrm{Cl}$ processes. A kinetic model of UV-based AOPs was established for the degradation of micro pollutants in wastewater, and the second-order rate constants of EfOM with radicals were evaluated.

\section{Materials and methods}

\subsection{Samples and chemicals}

Secondary wastewater effluent was obtained from a wastewater treatment plant in Beijing with a capacity of $1,000,000 \mathrm{~m}^{3} / \mathrm{d}$. The municipal sewage was purified by screens, aerated grit chambers and primary settling, and an $\mathrm{A}^{2} / \mathrm{O}$ process (anaerobic, anoxic and oxic conditions) and secondary clarification were carried out. The water parameters of the WWTP effluent are listed in Table 1.

Oxone was purchased from Alfa Aesar; $\mathrm{H}_{2} \mathrm{O}_{2}$ solution (30\%), sodium peroxydisulfate ( $>99 \%$ ), Sodium hypochlorite $(\mathrm{NaClO}, \geq 8 \%$ ), and 1,4-dimethoxybenzene (DMOB), benzoic acid (BA; 99\%) and tert-butyl alcohol $(t$-BuOH $>99.5 \%)$ were purchased from Sinopharm Chemical Reagent Co., Ltd. (Shanghai, China); para-chlorobenzoic acid (p-CBA; 98\%) was purchased from J\&K (Beijing, China); and methanol ( $>99.9 \%)$ and acetonitrile $(>99.9 \%)$ were purchased from J. T. Baker. Ultrapure deionized water (resistivity $>18.0 \mathrm{M} \Omega * \mathrm{~cm}$ ) was used in all experiments.

Table 1 Physico-chemical characteristics of raw EfOM

\subsection{UV-based advanced oxidation experiment}

The photo reactor used for the AOPs was equipped with a Xenon lamp peaking at $254 \mathrm{~nm}$ (CELHXUV300, Zhongjiao Jinyuan). The average UV fluence rate $\left(\mathrm{E}_{0}\right)$ was $1.217 \mathrm{~mW} \mathrm{~cm}^{-2}$. A $200-\mathrm{mL}$ test solution containing EfOM and 1.0 $\mu \mathrm{M}$ BA, $p$-CBA, or 5.0 $\mu \mathrm{M}$ DMOB was dosed with the oxidant stock solution (PS, PMS, $\mathrm{H}_{2} \mathrm{O}_{2}$ or $\mathrm{NaClO}$ ) and simultaneously exposed to $\mathrm{UV}$ irradiation at $25 \pm 0.2^{\circ} \mathrm{C}$. The oxidant dosages of the reaction were $0.588,1.176,2.352$ and $5.880 \mathrm{mM}$, respectively. Samples were collected at 10-min intervals for an hour, for further analysis. Reactions of UV/PS, UV/PMS and $\mathrm{UV} / \mathrm{H}_{2} \mathrm{O}_{2}$ were quenched with $100 \mathrm{mM}$ sulfite and $\mathrm{UV} / \mathrm{Cl}$ reactions were quenched with ascorbic acid at a molar ratio of [ascorbic acid] $/[$ chlorine] $=1.5: 1$. All tests were conducted at least twice. All data plots represent the average of the experimental data of the duplicated test results.

\subsection{Analytical methods}

High-performance liquid chromatography (HPLC; Waters 2695, USA) was used to determine [BA], [p-CBA] and [DMOB] (separation conditions given in Table S1). The column used in the liquid chromatographic analysis of BA, p-CBA and DMOB was a Waters Acquity UPLC BEH C18 $(1.7 \mu \mathrm{m}$, $2.1 \times 100 \mathrm{~mm}$ ). The dissolved organic matter in the EfOM was determined using a TOC analyzer (TOC; Shimadzu, Japan), and UV absorbance at $254 \mathrm{~nm}\left(\mathrm{UVA}_{254}\right)$ was measured using a UV/Vis (Evolution 300, Thermo Scientific, USA). Ion chromatography (ICS3000, Dionex Corp., USA) was used to determine $\left[\mathrm{Cl}^{-}\right],\left[\mathrm{NO}_{3}{ }^{-}\right]$, and $\left[\mathrm{HPO}_{3}{ }^{2-}\right]$. The separation was finished in an IonPac AS11 column with a 
constant gradient mode. The mobile phase eluent was $\mathrm{NaOH}$ solution $(30.0 \mathrm{mM})$ and the flow rate was $1.0 \mathrm{~mL} / \mathrm{min}$. Before the separation, $25.0 \mu \mathrm{L}$ of the sample was injected by an autosampler. The $\mathrm{pH}$ was measured using a pH meter (S210 Seven Compact, Mettler Toledo).

\subsection{Kinetic model of UV-based AOPs}

\subsubsection{Pseudo-first-order dynamics model}

Because UV irradiation showed no effect on the reference compound degradation (shown in Fig.1), and considering that the degradation reaction of the reference compound $(\mathrm{R})$ may be related to the oxidizing properties of the oxidants (PS, PMS and $\mathrm{H}_{2} \mathrm{O}_{2}$ ), $\mathrm{SO}_{4}{ }^{-}$and $\mathrm{HO}$, the degradation of $\mathrm{R}$ can be assumed to follow second-order kinetics:

$$
\begin{gathered}
\frac{d[R]}{d t}=k_{1}[P S][R]+k_{2}\left[S O_{4}^{-\cdot}\right][R]+k_{3}\left[H O^{\cdot}\right][R] \\
\frac{d[R]}{d t}=k_{4}[P M S][R]+k_{5}\left[S O_{4}^{-\cdot}\right][R]+k_{6}\left[\left[H O^{\cdot}\right]\right][R] \\
\frac{d[R]}{d t}=k_{7}\left[\mathrm{H}_{2} \mathrm{O}_{2}\right][R]+k_{8}\left[\left[H O^{\cdot}\right]\right][R]
\end{gathered}
$$

where $k_{\mathrm{i}}$ is the second-order rate constant of the reaction of PS, PMS, $\mathrm{H}_{2} \mathrm{O}_{2}, \mathrm{SO}_{4}{ }^{-*}$ and $\mathrm{HO}$ with R. It is known that the minimum concentration of PS, PMS or $\mathrm{H}_{2} \mathrm{O}_{2}$ is $0.588 \mathrm{mM}$, and it can be assumed that the BA and $p$-CBA concentration is $1.0 \mu \mathrm{M}$ [Oxidant] $\gg[\mathrm{R}]$. In order to simplify Eqs. (1)-(3), $k_{\text {app }}$ is introduced:

$$
\frac{d[R]}{d t}=k_{\mathrm{app}}[R]
$$

Then, the integral is transformed to

$$
-\ln \frac{[R]}{[R]_{0}}=k_{a p p} t
$$

where $k_{a p p}$ is the apparent reaction rate constant $\left(\mathrm{s}^{-1}\right)$, and $[\mathrm{R}]_{0}(\mathrm{mM})$ and $[\mathrm{R}](\mathrm{mM})$ represent the concentrations of $\mathrm{R}$ at the reaction times at 0 and $t$, respectively.

\subsubsection{Determination of second-order rate constants of $\mathrm{HO}^{\circ}$ and EfOM}

To quantify the reactivity of EfOM with $\mathrm{HO}$, the second-order rate constants $\left(k_{H O}, E f O M, \mathrm{MC}^{-1} \mathrm{~s}^{-1}\right)$ between $\mathrm{HO}^{\circ}$ and EfOM were determined based on the competition kinetics method using BA, $p$-CBA and $\mathrm{MeOH}$ (or $t-\mathrm{BuOH}$ ) in $\mathrm{UV} / \mathrm{H}_{2} \mathrm{O}_{2}$, since the reaction rate constants of $\mathrm{BA}, p-\mathrm{CBA}$ and $\mathrm{MeOH}$ (or $t$ $\mathrm{BuOH})$ with $\mathrm{HO}$ were known.

$k_{R}^{a p p}=k_{H O^{\prime}, R} \times\left[\mathrm{HO}^{\circ}\right]_{\mathrm{SS}}=k_{H O^{\prime} R} \times$

$\frac{\alpha_{H O}}{k_{H O}, \mathrm{EfOM}[\mathrm{EfOM}]+k_{\mathrm{HO}}, \mathrm{MeOH} / \mathrm{t}-\mathrm{BuOH}[\mathrm{MeOH} / \mathrm{t}-\mathrm{BuOH}]+k_{\mathrm{HO} ;}[\mathrm{R}]+k_{\mathrm{HO}} ; \mathrm{H}_{2} \mathrm{O}_{2}\left[\mathrm{H}_{2} \mathrm{O}_{2}\right]}$

Then,

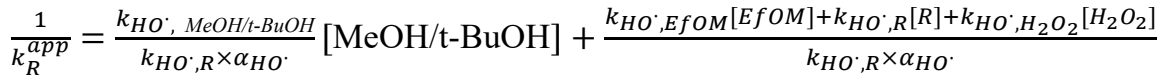

where $k_{R}^{a p p}$ is the apparent degradation rate constant of $\mathrm{R}\left(\mathrm{s}^{-1}\right)$, and $k_{H O, R}$ is the second-order rate constant for the reaction between $\mathrm{HO}^{-}$and compound $\mathrm{R}\left(\mathrm{M}^{-1} \mathrm{~s}^{-1}\right)$. $\left[\mathrm{HO}^{-}\right]_{\mathrm{ss}}$ is the steady-state concentration of $\mathrm{HO}(\mathrm{M})$, and $\alpha_{\mathrm{HO}}$ is the formation rate of $\mathrm{HO}^{\cdot}\left(\mathrm{M} \mathrm{s}^{-1}\right)$. 
In order to eliminate the capture of hydroxyl radicals by inorganic ions in the EfOM and determine the concentrations of $\mathrm{Cl}^{-}, \mathrm{NO}_{3}{ }^{-}$and $\mathrm{HPO}_{3}{ }^{2-}$, we introduced the parameter $\beta$ :

$$
\beta=\mathrm{k}_{9} \times\left[\mathrm{Cl}^{-}\right]+\mathrm{k}_{10} \times\left[\mathrm{NO}_{3}{ }^{-}\right]+\mathrm{k}_{11} \times\left[\mathrm{HPO}_{3}{ }^{2-}\right]
$$

where $\mathrm{k}_{9}, \mathrm{k}_{10}, \mathrm{k}_{11}$ are the second-order rate constants of $\mathrm{HO}$ with $\mathrm{Cl}^{-}, \mathrm{NO}_{3}^{-}$and $\mathrm{HPO}_{3}{ }^{2-}$, respectively.(Alfassi et al., 1988; Buxton et al., 1988; Herrmann et al., 1999)

Bringing $\beta$ into Eq. 7 gives

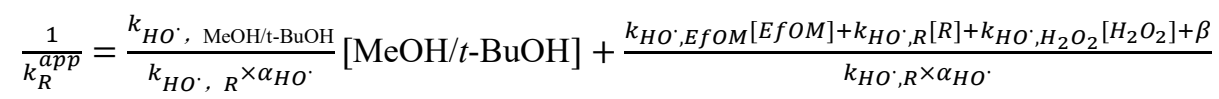

\subsubsection{Determination of second-order rate constants of $\mathrm{SO}_{4}^{-\cdot}$ and EfOM}

Similar to calculating the secondary reaction rate of $\mathrm{HO}$ with EfOM, the second-order rate constant $\left(k_{\mathrm{SO}_{4}}{ }^{-{ }^{-}, \mathrm{EFOM}}, \mathrm{MC}^{-1} \mathrm{~s}^{-1}\right)$ of the reaction between EfOM and $\mathrm{SO}_{4}{ }^{-}$is the same as above, using BA, $p$-CBA and $\mathrm{MeOH}$ (or $t-\mathrm{BuOH}$ ) in the UV/PS system and UV/PMS system.

$$
\gamma=\mathrm{k}_{12} \times\left[\mathrm{Cl}^{-}\right]+\mathrm{k}_{13} \times\left[\mathrm{NO}_{3}{ }^{-}\right]+\mathrm{k}_{14} \times\left[\mathrm{HPO}_{3}{ }^{2-}\right]
$$

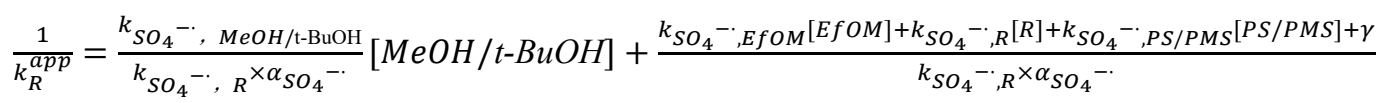

(11)

where $\mathrm{k}_{12}, \mathrm{k}_{13}$ and $\mathrm{k}_{14}$ are the second-order rate constants of $\mathrm{SO}_{4}{ }^{-\cdot}$ with $\mathrm{Cl}^{-}, \mathrm{NO}_{3}{ }^{-}$and $\mathrm{HPO}_{3}{ }^{2-}$, respectively; $k_{R}^{a p p}$ is the apparent degradation rate constant of $\mathrm{R}\left(\mathrm{s}^{-1}\right) ; k_{\mathrm{SO}_{4}}{ }^{-{ }^{-}, R}$ is the second-order rate constant for the reaction between $\mathrm{SO}_{4}^{--}$and compound "R;" and $\alpha_{\mathrm{SO}_{4}^{--}}$is the formation rate of $\mathrm{SO}_{4}^{--}\left(\mathrm{M} \mathrm{s}^{-1}\right)$.

\subsubsection{Determination of second-order rate constants of $\mathrm{ClO}^{\circ}$ and $\mathrm{EfOM}$}

The second-order rate constants $\left(k_{\mathrm{ClO}} \bullet\right.$ ) for the reaction of $\mathrm{ClO}$ with $\mathrm{EfOM}$ were determined by competition kinetics between EfOM and a reference compound of 1,4-dimethoxybenzene (DMOB), which was selected to be the reference compound because of its available $\mathrm{k}$ value with $\mathrm{ClO}$ of $2.1 \times 10^{9}$ $\mathrm{M}^{-1} \mathrm{~s}^{-1}$. The pseudo-first order rate constant $\left(k^{\prime}\right)$ of DMOB varied depending on the presence or absence of EfOM, as shown in Eq 12:

$$
\frac{k_{\mathrm{R}-0}^{\prime}}{k_{\mathrm{R}-i}^{\prime}}=1+\frac{k_{\mathrm{ClO} \cdot \mathrm{EfOM}}}{k_{\mathrm{ClO}, \mathrm{B}}} \times \frac{[\mathrm{EfOM}]_{0}}{[\mathrm{R}]_{0}}
$$

where $[\mathrm{EfOM}]_{0}$ and $[\mathrm{R}]_{0}$ represent the initial concentrations of the EfOM and the DMOB respectively; $k_{R-0}^{\prime}$ and $k_{R-i}^{\prime}$ represent the $k^{\prime}$ of the reference compound (DMOB) in the absence and presence of

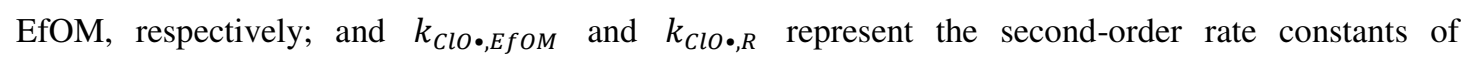
$\mathrm{ClO}$ reacting with the EfOM and the DMOB, respectively. (Guo et al., 2018)

\section{Results and discussion}

\subsection{Removal efficiencies of reference compounds in EfOM by UV/ oxidants}

Fig. 1 Degradation profile of probes (BA and $p$-CBA) in UV-based AOP: (A) UV/ $\mathrm{H}_{2} \mathrm{O}_{2}$, (B) UV/PS, (C) UV/PMS, (D) UV/Cl; 1-BA, 2-pCBA.

Reaction conditions: [BA or $p-\mathrm{CBA}]=1.0 \mu \mathrm{M}, \mathrm{E}_{0}=1.217 \mathrm{~mW} \mathrm{~cm}^{-2}$, solution $\mathrm{pH}=7.9$ 
Fig. 1 compares the degradation of BA (or $p$-CBA) by the $\mathrm{UV} / \mathrm{H}_{2} \mathrm{O}_{2}, \mathrm{UV} / \mathrm{PS}, \mathrm{UV} / \mathrm{PMS}$ and UV/Cl systems at different oxidant concentrations in EfOM and ultrapure water. BA and $p$-CBA are commonly used as radical probe compounds in UV-based AOPs because they have high reactivity with radicals, especially with $\mathrm{HO}^{-}$and $\mathrm{SO}_{4}^{-{ }^{-}}$. On the whole, probe compounds have the best degradation effect in ultrapure water, as the concentration of oxidants is $0.588 \mathrm{mM}$ background in different oxidation systems. The degradation rates of $\mathrm{BA}$ in the $\mathrm{UV} / \mathrm{H}_{2} \mathrm{O}_{2}$, UV/PS, UV/PMS, and UV/Cl systems were 86.07\%, $79.05 \%, 56.94 \%$ and $54.91 \%$, respectively, and the degradation rates of $p$-CBA in the $\mathrm{UV} / \mathrm{H}_{2} \mathrm{O}_{2}, \mathrm{UV} / \mathrm{PS}$, $\mathrm{UV} / \mathrm{PMS}$ and $\mathrm{UV} / \mathrm{Cl}$ systems were $69.42 \%, 50.17 \%, 44.77 \%$ and $60.02 \%$, respectively. It can be concluded that the AOPs had the potential to degrade the contaminants. The pseudo-first-order reaction rate constants for BA were $4.90 \times 10^{-4}, 3.54 \times 10^{-4}, 2.31 \times 10^{-4}$ and $2.14 \times 10^{-4} \mathrm{~cm}^{2} \mathrm{~mJ}^{-1}$ in the $\mathrm{UV} / \mathrm{H}_{2} \mathrm{O}_{2}$, $\mathrm{UV} / \mathrm{PS}, \mathrm{UV} / \mathrm{PMS}$ and UV/Cl systems, respectively, and the pseudo-first-order reaction rate constants for p-CBA were $2.73 \times 10^{-4}, 1.55 \times 10^{-4}, 1.60 \times 10^{-4}$ and $2.58 \times 10^{-4} \mathrm{~cm}^{2} \mathrm{~mJ}^{-1}$ in the $\mathrm{UV} / \mathrm{H}_{2} \mathrm{O}_{2}, \mathrm{UV} / \mathrm{PS}, \mathrm{UV} / \mathrm{PMS}$ and $\mathrm{UV} / \mathrm{Cl}$ systems, respectively (as shown in Table $\mathrm{S} 2$ ). It can be seen that the reaction rates of BA were higher than those of $p$-CBA in the $\mathrm{UV} / \mathrm{H}_{2} \mathrm{O}_{2}$, UV/PS and UV/PMS systems, indicating that the reaction mechanisms between the two probes and the radicals ( $\mathrm{HO}$ and $\mathrm{SO}_{4}^{-{ }^{-}}$) differed. The reaction rate was opposite in the $\mathrm{UV} / \mathrm{Cl}$ system, where the degradation of $p$-CBA in ultrapure water was significantly faster than the degradation of BA, while the opposite results were obtained in the EfOM background.

The degradation of BA and $p$-CBA in the secondary effluent organic matter by UV alone had little effect. The efficiency of the degradation rate of the two probes under UV irradiation showed a significant concentration of oxidants increased, the degradation efficiency of the probe compounds also increased, indicating that the concentration of radicals increased. But this increase was not continuous. It can be seen that when the concentration reached $5.880 \mathrm{mM}$, the degradation efficiency was basically the same as for the concentration of $2.352 \mathrm{mM}$. For example, the pseudo-first-order reaction rate constant for BA was $1.13 \times 10^{-4} \mathrm{~cm}^{2} \mathrm{~mJ}^{-1}$ with a PS concentration of $2.235 \mathrm{mM}$, and the reaction rate constant for BA was $1.15 \times 10^{-4} \mathrm{~cm}^{2} \mathrm{~mJ}^{-1}$ with a concentration of $5.880 \mathrm{mM}$ in the UV/PS system. The reason for this difference is that the concentration of the micro-contaminant was limited, in the wastewater. When the concentration of free radicals reaches a certain value, the reaction is saturated. Therefore, an oxidant concentration of $2.352 \mathrm{mM}$ was selected for the next experiment.

The degradation rate of the $\mathrm{UV} / \mathrm{H}_{2} \mathrm{O}_{2}$ system was higher than for other processes. For example, the pseudo-first-order reaction rate constants for BA were $1.64 \times 10^{-4}, 1.13 \times 10^{-4}, 1.56 \times 10^{-4}$, and $1.57 \times 10^{-4}$ $\mathrm{cm}^{2} \mathrm{~mJ}^{-1}$ in $\mathrm{UV} / \mathrm{H}_{2} \mathrm{O}_{2}$, UV/PS, UV/PMS and UV/Cl systems, respectively, with a 2.352-mM concentration of oxidants in the presence of EfOM. In the $\mathrm{UV} / \mathrm{H}_{2} \mathrm{O}_{2}$ system, the major oxidant was the hydroxyl radical ( $\mathrm{HO}^{\prime}$ ); the reaction is shown below (Reaction 1). $\mathrm{H}_{2} \mathrm{O}_{2}$ is decomposed to generate a powerful oxidant $\mathrm{HO} \bullet$ under the irradiation of ultraviolet light and to trigger free radical chain reactions. PS is stable at room temperature, and the UV led to the cleavage of the O-O bond of PS and generated two $\mathrm{SO}_{4}{ }^{-*}$ molecules (Reaction 2), which was efficient at degrading the probes. Compared to PDS, PMS has a shorter bond, and more energy is required to cleave the peroxide bond and generate $\mathrm{HO}^{\circ}$ and $\mathrm{SO}_{4}^{--}$(Reaction 3). The redox potential of $\mathrm{SO}_{4}^{--}$is equal to or even better than $\mathrm{HO}$ (Ghauch and Tuqan, 2012) but $\mathrm{SO}_{4}^{--}$is more selective than $\mathrm{HO}^{-}$in degrading the contaminants, which may have led to the lower degradation rate in the UV/PMS and UV/PDS than in the UV/ $\mathrm{H}_{2} \mathrm{O}_{2}$ system. In the UV/Cl system, there are several kinds of radicals, such as $\mathrm{OH}^{\circ}, \mathrm{Cl}^{-}, \mathrm{ClO}$, and $\mathrm{Cl}_{2}{ }^{--}$, that are responsible for degrading the probes in the effluent organic matter (Reactions 5-10). 
In particular, a large amount of $\mathrm{SO}_{4}^{--}$is transformed to $\mathrm{HO}$ under basic conditions (Reaction 4). In the presence of $\mathrm{p}-\mathrm{CBA}$, the conditions are more acidic compared to those in the presence of $\mathrm{BA}$, indicating that the degradation rate of $\mathrm{BA}$ is higher than that of $\mathrm{p}-\mathrm{CBA}$. Besides, the main reaction of $\mathrm{BA}$ with $\mathrm{HO}$ is the direct attack of the $\mathrm{HO}^{\circ}$ on the aromatic ring to form a hydroxy-substituted compound.(Singla et al., 2004) However, the reaction of $\mathrm{SO}_{4}^{-{ }^{-*}}$ with BA first leads to the formation of a radical cation followed by hydrolysis, to form 4-hydroxybenzoic acid (HBA).(Ying-Hong et al., 2011a) This is why the BA degrades faster in $\mathrm{UV} / \mathrm{H}_{2} \mathrm{O}_{2}$ than in the UV/PS or UV/PMS systems.

Table 2 Reactions involved in the different UV-based advanced oxidation processes

In the UV/PS system, the degradation efficiencies of BA and $p$-CBA were $40.66 \%$ and $26.85 \%$, respectively, at the concentration of $5.880 \mathrm{mM}$ in the presence of EfOM. Under the same conditions, the degradation efficiencies under UV/PMS were $44.04 \%$ and $28.35 \%$, respectively. Mahdi-Ahmed(MahdiAhmed and Chiron, 2014) and Minhwan Kwon(Lee et al., 2018) also found that the removal rate of the probe compound in the UV/PS process is higher than that of the UV/PMS process in ultrapure water, whereas the UV/PMS process has a higher removal rate of the probe compound than the UV/PS process in wastewater from a sewage treatment plant. Guan's research results proved that UV/PMS significantly enhances the degradation of BA in the $\mathrm{pH}$ range of 9-11, while the concentration of PMS has little effect.(Ying-Hong et al., 2011b)

By comparing the degradation results in ultrapure water and EfOM, we observed that the degradation of the probe compound by different oxidant concentrations in EfOM is not as effective as in ultrapure water. It can be reasonably inferred that this is most likely because the organic matter contained in EfOM has a trapping effect on the radicals, which leads to different results in the degradation of the probe compound by different oxidation systems. Therefore, we elected to use the competition kinetics method to calculate the second-order rate constants of EfOM and radicals.

\subsection{Contribution of different radicals to contaminant degradation in EfOM}

To demonstrate the $\mathrm{HO}^{-}$and $\mathrm{SO}_{4}{ }^{-}$reactivity with the EfOM, the second-order rate constants between radicals and the EfOM were determined based on the competition kinetics method using probes (BA, $p$ CBA) and inhibitors $\left(\mathrm{MeOH}, t\right.$-BuOH) in the UV/PS, UV/PMS and $\mathrm{UV} / \mathrm{H}_{2} \mathrm{O}_{2}$ systems. The initial concentration of $\mathrm{MeOH}$ ( or $t-\mathrm{BuOH}$ ) was varied from $0 \mathrm{mM}$ to $0.10 \mathrm{mM}$, and the initial concentrations of probes and oxidants were fixed at $1.0 \mu \mathrm{M}$ and $2.352 \mathrm{mM}$, respectively. The introduction of $\mathrm{MeOH}$ and $t$ - $\mathrm{BuOH}$ significantly inhibited the degradation of probes in UV/PS, UV/PMS and UV/ $\mathrm{H}_{2} \mathrm{O}_{2}$ compared to results in the absence of quencher, indicating that $\mathrm{HO}^{-}$and $\mathrm{SO}_{4}{ }^{-}$are the main reactive oxidizing species. In the sulfate radical systems, when $0.1 \mathrm{mM}$ of radical scavenger was applied, the removal efficiency of BA and $p$-CBA was reduced by about $30 \%$ in the presence of $\mathrm{MeOH}$ (Fig. 2); while almost no BA or $p$ CBA decrease was observed with the addition of $t$-BuOH (Table S3 and Fig. 3). These results indicated that $\mathrm{SO}_{4}{ }^{-}$was the predominant reactive species in the UV/PS and UV/PMS systems, a result consistent with a study by Osburn.(Osburn et al., 2009) Fig. 4 and Fig. 5 show the experimental results of the competition kinetics for the calculation of the second-order rate constants. Due to the reactivity of $\mathrm{ClO}$, the second-order rate constant for the reaction between $\mathrm{ClO}^{\circ}$ and EfOM was determined using DMOB as a reference compound with varying EfOM concentrations, which react with $\mathrm{ClO}$ at the second-order rate constant of $2.1 \times 10^{9} \mathrm{M}^{-1} \mathrm{~s}^{-1}$ (Alfassi et al., 1988) (Fig. 6). 
Fig. 2 Pseudo primary degradation of added $\mathrm{MeOH}$ in EfOM (includes BA and $p$-CBA) Reaction conditions: $[\mathrm{BA}]_{0}=[p-\mathrm{CBA}]_{0}=1.0 \mu \mathrm{M},[\mathrm{PS}]_{0}=[\mathrm{PMS}]_{0}=\left[\mathrm{H}_{2} \mathrm{O}_{2}\right]_{0}=2.352 \mathrm{mM}$, $[\mathrm{MeOH}]_{0}=0,10,20,50$ 和 $100 \mathrm{Mm}$

Fig. 3. Pseudo primary degradation of added t-BuOH in EfOM (includes BA and p-CBA) Reaction conditions: $[\mathrm{BA}]_{0}=[\mathrm{p}-\mathrm{CBA}]_{0}=1.0 \mu \mathrm{M}, \quad[\mathrm{PS}]_{0}=[\mathrm{PMS}]_{0}=\left[\mathrm{H}_{2} \mathrm{O}_{2}\right]_{0}=2.352 \mathrm{mM}[\mathrm{t}-\mathrm{BuOH}]_{0}$ $=0,10,20,50$ 和 $100 \mu \mathrm{M}$

Fig. 4 Reciprocal of the apparent rate constants for BA and $p$ CBA $v s$. MeOH concentrations: (a) UV/ $\mathrm{H}_{2} \mathrm{O}_{2}$ system; (b) UV/PS system; (c) UV/PMS system

Reaction conditions: [BA or $p-\mathrm{CBA}]_{0}=1.0 \mu \mathrm{M}$, [oxidant $]_{0}=2.352 \mathrm{mM}, \mathrm{E}_{0}=1.217 \mathrm{~mW} \mathrm{~cm}^{-2}$, solution $\mathrm{pH}=7.9$

Fig. 5 Competitive dynamics of BA and p-CBA at different tert-butanol concentrations Reaction conditions: $[\mathrm{BA}]_{0}=[\mathrm{p}-\mathrm{CBA}]_{0}=1.0 \mu \mathrm{M},[\mathrm{PS}]_{0}=[\mathrm{PMS}]_{0}=\left[\mathrm{H}_{2} \mathrm{O}_{2}\right]_{0}=2.352 \mathrm{mM}[\mathrm{t}-\mathrm{BuOH}]_{0}$ $=0,10 、 20 、 50$ 和 $100 \mu \mathrm{M}$

Fig. 6 Competition kinetic plot for $\mathrm{ClO}^{\bullet}$ reaction with EfOM using 1,4-dimethoxybenzene (DMOB) as a reference compound.

Reaction conditions: $[\text { chlorine }]_{0}=2.353 \mathrm{mM},[\mathrm{DMOB}]_{0}=5.0 \mu \mathrm{M},[\mathrm{EfOM}]_{0}=0,1444,3344,5244,6384$ $\mu \mathrm{g} \mathrm{L}^{-1}$

Table S6 lists the second-order rate constants determined for the reactions between the EfOM and radicals. To verify the method and rate constants determined in this study, both probes and inhibitors were measured in each of the different oxidation systems. The second-order rate constant of EfOM and HO was determined to be $(3.192 \pm 0.153) \times 10^{4}(\mathrm{mg}-\mathrm{C} / \mathrm{L})^{-1} \mathrm{~s}^{-1}$, which is within the commonly reported range of second-order rate constants. These rate constants are similar to the $10^{3}-10^{11} \mathrm{M}^{-1} \mathrm{~s}^{-1}$ range of second-order rate constants for the reaction of organics with $\mathrm{HO}^{-}$presented in the literature: these are

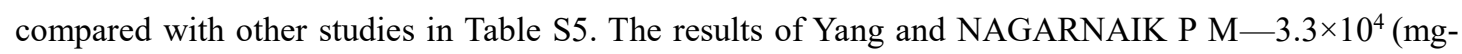
$\mathrm{C} / \mathrm{L})^{-1} \mathrm{~s}^{-1}$ and $(7.1 \pm 0.81) \times 10^{4}(\mathrm{mg}-\mathrm{C} / \mathrm{L})^{-1} \mathrm{~s}^{-1}$, respectively(Nagarnaik and Boulanger, 2011; Yang et al., 2016) - are very similar to our findings. In the sulfate radical-mediated oxidation system, the error of the determined rate constant $\left(k_{S_{0}{ }_{4}{ }^{-}, \text {EfOM }}=(5.027 \pm 0.643) \times 10^{2}\left(\left(\mathrm{mg}-\mathrm{C} / \mathrm{L}^{-1} \mathrm{~s}^{-1}\right)\right.\right.$ in this study was small, indicating the reliability of the measurement method. And compared with the other studies shown in Table S4, Yang's samples of EfOM were isolated from RO Brine A by solid-phase extraction, and contain a large amount of chloride ions, exceeding the probe compounds concentration by 1300 - to 2300 -fold. They observed that $\mathrm{SO}_{4}{ }^{-*}$ can be converted to more selective halogen and carbonate radicals, resulting in a wider range of degradation efficiencies among the contaminants.(Yang et al., 2016) Zhou measured the absolute rate constants of the reaction of $\mathrm{SO}_{4}{ }^{-*}$ with four types of organic matter: two fulvic acids and two types of lake organic matter, and their results were close to those in our research.(Zhou et al., 2017) The differences in the organic matter contained in the effluent are the main cause of the difference in research results, and are also related to the choice of secondary biochemical reaction process.

Because the $\mathrm{UV} / \mathrm{Cl}$ process is an emerging advanced oxidation process (AOP) used for the degradation of micropollutants, there has been little research on the secondary reaction rate constant of $\mathrm{ClO}$ reacting with different substances in aqueous systems. The second-order kinetic rate constant for EfOM with a chlorooxyl radical was calculated to be $1.35 \times 10^{6}(\mathrm{mg}-\mathrm{C} / \mathrm{L})^{-1} \mathrm{~s}^{-1}$ in this research. This value is two orders of magnitude higher than that from EfOM from the Tai Cang wastewater treatment plant in Shanghai$1.83 \times 10^{4}(\mathrm{mg}-\mathrm{C} / \mathrm{L})^{-1} \mathrm{~s}^{-1}$. (Guo et al., 2018) Guo(Guo et al., 2017) researched simulated drinking water prepared by spiking NOM in pure water $\left(1 \mathrm{mg} \mathrm{L}^{-1}\right)$, and the $\mathrm{k}$ value of the organic matter with $\mathrm{ClO}$ was $4.52 \times 10^{4}(\mathrm{mg}-\mathrm{C} / \mathrm{L})^{-1} \mathrm{~s}^{-1}$. The difference in $\mathrm{k}$ values between the organic matter of different sources and 


\subsection{Calculating the radical production rate in EfOM}

It is well known that a wastewater matrix such as carbonate species and EfOM affects the removal efficiency of a reference compound (R) in a radical-mediated system.(Rosenfeld and Linden, 2007; Yuan et al., 2011) Von Gunten and Linden introduced the concept of $R_{c t}$ to model these complex matrix effects in different AOPs.(Elovitz et al., 2000b; Rosenfeld and Linden, 2007) The $\mathrm{R}_{\mathrm{ct}}$ concept, defined as the experimentally determined radical exposure per UV fluence for a given water matrix and initial oxidants concentration, can characterize the effectiveness of the UV/oxidant AOPs within a specific water matrix.(Elovitz et al., 2000a) To quantify the scavenging effect of the EfOM, $R_{\mathrm{HO}, U V}$, and $R_{\mathrm{SO}_{4}{ }^{-}, U V}$ were calculated with Eqs. (12) and (13), respectively:

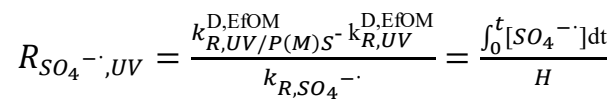

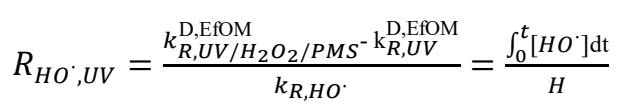

where $k_{R, U V}^{D, E f O M}$ is the apparent first-order rate constant $\left(\mathrm{s}^{-1}\right)$ of $\mathrm{R}$ destruction in EfOM under UV conditions, and $k_{R, U V / \text { Oxidants }}^{\mathrm{D}, \mathrm{EFOM}}$ is the apparent first-order rate constant $\left(\mathrm{s}^{-1}\right)$ of $\mathrm{R}$ degradation in the UV/oxidants system in the presence of EfOM. The superscript " $D$ " indicates that the value is fluencebased. UV fluence ( $\mathrm{H}$ in the unit of $\mathrm{mJ} \mathrm{cm}^{-2}$ ) is simply the product of $\mathrm{E}_{0}$ and $\mathrm{t}$. The detailed calculation method refers to the study of Gao et al. (Gao et al., 2019)

Figure 7 displays the first-order degradation kinetics of probe compounds as a function of applied UV fluence at EfOM in the different UV/oxidant systems. The decay is first order with UV fluence, with only one kinetic regime throughout. Through Figure 7, we can use Formulas (13) and (14) to calculate the data in Table $\mathrm{S} 7$, which illustrates the $\mathrm{R}_{\mathrm{ct}}$ values of $\mathrm{SO}_{4}^{-{ }^{-}}$and $\mathrm{HO}$ to $\mathrm{BA}$ or $p-\mathrm{CBA}$ degradation in a $\mathrm{UV} / \mathrm{PS}, \mathrm{UV} / \mathrm{PMS}$ or $\mathrm{UV} / \mathrm{H}_{2} \mathrm{O}_{2}$ system. When BA is used as a probe, UV/PS produces an $\mathrm{SO}_{4}{ }^{--}$value of $9.42 \times 10^{-14} \mathrm{M} \mathrm{s} \mathrm{cm}^{2} \mathrm{~mJ}^{-1}$, and UV/PMS produces two kinds of radicals $-\mathrm{HO}$ and $\mathrm{SO}_{4}^{--}-2.64 \times 10^{-14} \mathrm{M} \mathrm{s}$ $\mathrm{cm}^{2} \mathrm{~mJ}^{-1}$ and $1.30 \times 10^{-13} \mathrm{M} \mathrm{s} \mathrm{cm}^{2} \mathrm{~mJ}^{-1}$, of which the one mainly producing $\mathrm{SO}_{4}^{--}$accounted for $83.1 \%$. The $\mathrm{HO}$ produced by $\mathrm{UV} / \mathrm{H}_{2} \mathrm{O}_{2}$ was $2.78 \times 10^{-14} \mathrm{M} \mathrm{s} \mathrm{cm}^{2} \mathrm{~mJ}^{-1}$. And using $p$-CBA as a probe, UV/PS produced $\mathrm{SO}_{4}^{--}$of $1.94 \times 10^{-13} \mathrm{M} \mathrm{s} \mathrm{cm}^{2} \mathrm{~mJ}^{-1}$, while $\mathrm{HO}$ and $\mathrm{SO}_{4}^{--}$in UV/PMS produced fluxes of $1.78 \times 10^{-}$ ${ }^{14} \mathrm{M} \mathrm{s} \mathrm{cm}^{2} \mathrm{~mJ}^{-1}$ and $2.48 \times 10^{-13} \mathrm{M} \mathrm{s} \mathrm{cm}^{2} \mathrm{~mJ}^{-1}$, and the proportion of $\mathrm{SO}_{4}^{--}$was $93.3 \%$. The HO produced by $\mathrm{UV} / \mathrm{H}_{2} \mathrm{O}_{2}$ was $2.66 \times 10^{-15} \mathrm{M} \mathrm{s} \mathrm{cm}^{2} \mathrm{~mJ}^{-1}$. By comparing the scavenging effects of different oxidation systems on the two probes, it can be observed that the $\mathrm{SO}_{4}^{--}$produced by UV/PS and UV/PMS was more effective. Although the degradation of EfOM is more rapid in $\mathrm{UV} / \mathrm{H}_{2} \mathrm{O}_{2}, \mathrm{SO}_{4}{ }^{-}$is more reactive with specific contaminants than $\mathrm{HO}$, in the degradation of specific pollutants.

In general, the most useful application of the $\mathrm{R}_{\mathrm{ct}}$ parameter may be in calculating the scavenging properties of the wastewater matrix(Rosenfeld and Linden, 2007) and assessing the potential of $\mathrm{SO}_{4}^{--}$ based AOPs in wastewater treatment systems. We used a method of experimentally assessing the exposures of radicals in UV/oxidant AOPs. This parameter can be used to compare water-matrix effects on such UV/oxidant AOPs, to compare the model oxidation of environmental pollutants of concern during AOP treatments in different types of water. This parameter can also be useful in comparing efficiencies among several AOPs. 
Fig. 7 Pseudo-first-order degradation of BA (or p-CBA) by different oxidant concentrations in EfOM and ultrapure water

Reaction conditions: [BA or $p-\mathrm{CBA}]=1.0 \mu \mathrm{M}, \mathrm{E}_{0}=1.217 \mathrm{~mW} \mathrm{~cm}^{-2}$, solution $\mathrm{pH}=7.9$

\section{Conclusions}

The effect of UV-based advanced oxidation processes $\left(\mathrm{UV} / \mathrm{H}_{2} \mathrm{O}_{2}, \mathrm{UV} / \mathrm{PS}, \mathrm{UV} / \mathrm{PMS}, \mathrm{UV} / \mathrm{Cl}\right)$ in degrading probes (BA, p-CBA, DMOB) in the absence or presence of EfOM was investigated. Direct UV photolysis is not effective because of the low quantum yield. With the addition of oxidants $\left(\mathrm{H}_{2} \mathrm{O}_{2}\right.$, PS, PMS, $\mathrm{NaClO}$ ), the removal rate was largely improved due to the formation of $\mathrm{HO}$, $\mathrm{SO}_{4}^{--}$and $\mathrm{ClO}$. As the concentration of oxidants increases, the degradation efficiency of the probe compounds also increases. The oxidant concentration of $2.352 \mathrm{mM}$ was selected to degrade the probes. Due to its different degradation mechanism, the reaction rate of BA was higher than $p$-CBA in the $\mathrm{UV} / \mathrm{H}_{2} \mathrm{O}_{2}, \mathrm{UV} / \mathrm{PS}$ and UV/PMS systems. The degradation rates of $\mathrm{BA}$ decreased in the order $\mathrm{UV} / \mathrm{H}_{2} \mathrm{O}_{2}>\mathrm{UV} / \mathrm{PS}>\mathrm{UV} / \mathrm{PMS}>\mathrm{UV} / \mathrm{Cl}$, whereas the order of the $p$-CBA degradation rates was $\mathrm{UV} / \mathrm{H}_{2} \mathrm{O}_{2}>\mathrm{UV} / \mathrm{Cl}>\mathrm{UV} / \mathrm{PS}>\mathrm{UV} / \mathrm{PMS}$ in ultrapure water. With the competition kinetics method using a probe (BA, $p$-CBA) and inhibitors $(\mathrm{MeOH}, t-\mathrm{BuOH})$ in the $\mathrm{UV} / \mathrm{PS}, \mathrm{UV} / \mathrm{PMS}$ and $\mathrm{UV} / \mathrm{H}_{2} \mathrm{O}_{2}$ systems, results indicated that $\mathrm{HO}^{-}$and $\mathrm{SO}_{4}^{-{ }^{-}}$are the principal radicals. The second-order rate constants of the EfOM with radicals were determined to be $(3.192 \pm 0.153) \times 10^{4} \mathrm{M} \mathrm{s} \mathrm{cm}^{2} \mathrm{~mJ}^{-1}\left(\mathrm{HO}^{-}\right),(5.027 \pm 0.643) \times 10^{2}$ $\mathrm{M} \mathrm{s} \mathrm{cm}^{2} \mathrm{~mJ}^{-1}\left(\mathrm{SO}_{4}^{--}\right)$and $1.35 \times 10^{6} \mathrm{M} \mathrm{s} \mathrm{cm}^{2} \mathrm{~mJ}^{-1}(\mathrm{ClO})$. With the introduction of $\mathrm{R}_{\mathrm{ct}}$ to the wastewater, results indicated that $\mathrm{SO}_{4}{ }^{--}$was the principal radical in the UV/PMS and UV/PS systems, and $\mathrm{HO}^{\circ}$ is the principal radical in $\mathrm{UV} / \mathrm{H}_{2} \mathrm{O}_{2}$.

\section{Declarations}

\section{Ethics approval and consent to participate}

Not applicable

\section{Consent for publication}

$$
\text { Not applicable }
$$

\section{Availability of data and materials}

All data generated or analyzed during this study are included in this published article and its supplementary information files.

\section{Competing interests}

The authors declare that they have no competing interests.

\section{Funding}

This work is supported by National Water Pollution Control and Management Technology Major Project (2018ZX07110005), the National Natural Science Foundation of China (51578037), the Guangxi Province Technology Major Project (AA17202032), the Scientific Research Program of Beijing 
Municipal Education Commission (KM201610016001) and the Fundamental Research Funds for Beijing University of Civil Engineering and Architecture (X18288, X18289 and X20137).

\section{Authors' contributions}

DY: Writing-Editing \& Review, Funding acquisition; GL: Data curation, Writing-Original draft preparation; FQ: Writing-Editing \& Review, Conceptualization; JW: Writing-Review, Visualization; YK: Writing-Editing \& Review, Funding acquisition; YC: Investigation; MB: Visualization; XL: Methodology

\section{References}

Alfassi, Z. B., Huie, R. E., Mosseri, S., and Neta, P. (1988). Kinetics of one-electron oxidation by the $\mathrm{ClO}$ radical. International Journal of Radiation Applications \& Instrumentation.part C.radiation Physics \& Chemistry 32, 3888-3891.

And, G. P. A., and Dionysiou, D. D. (2004). Radical Generation by the Interaction of Transition Metals with Common Oxidants. Environmental Science \& Technology 38, 3705.

And, P. L. B., and Fulkersonbrekken $\dagger$, J. (1998). Nitrate-Induced Photolysis in Natural Waters: Controls on Concentrations of Hydroxyl Radical Photo-Intermediates by Natural Scavenging Agents. Environmental Science \& Technology 32, 3004-3010.

Beitz, T., Bechmann, W., and Mitzner, R. (1998). Investigations of Reactions of Selected Azaarenes with Radicals in Water. 2. Chlorine and Bromine Radicals. Journal of Physical Chemistry A 102, 6766-6771.

Buxton, G. V., Greenstock, C. L., Helman, W. P., and Ross, A. B. (1988). Critical Review of rate constants for reactions of hydrated electrons, hydrogen atoms and hydroxyl radicals ( $\mathrm{OH} / \mathrm{O}-$ in Aqueous Solution. Journal of Physical and Chemical Reference Data 17, 513-886.

Cong, J., Wen, G., Huang, T., Deng, L., and Ma, J. (2015). Study on enhanced ozonation degradation of para-chlorobenzoic acid by peroxymonosulfate in aqueous solution. Chemical Engineering Journal 264, 399-403.

Das, T. N. (2017). Reactivity and role of SO5•- radical in aqueous medium chain oxidation of sulfite to sulfate and atmospheric sulfuric acid generation. Journal of Physical Chemistry A 105, 9142-9155.

Donham, J. E., Rosenfeldt, E. J., and Wigginton, K. R. (2014). Photometric hydroxyl radical scavenging analysis of standard natural organic matter isolates. Environmental Science Processes \& Impacts 16, 764-769.

Elovitz, M. S., Gunten, U. V., and Kaiser, H. P. (2000a). Hydroxyl Radical/Ozone Ratios During Ozonation Processes. II. The Effect of Temperature, $\mathrm{pH}$, Alkalinity, and DOM Properties. Ozone Science \& Engineering 22, 123-150.

Elovitz, M. S., von Gunten, U., and Kaiser, H.-P. (2000b). Hydroxyl Radical/Ozone Ratios During Ozonation Processes. II. The Effect of Temperature, $\mathrm{pH}$, Alkalinity, and DOM Properties. Ozone Science \& Engineering 22, 123-150.

Feng, Y., Smith, D. W., and Bolton, J. R. (2007). Photolysis of aqueous free chlorine species ( $\mathrm{HOCl}$ and $\mathrm{OCl}-$ ) with $254 \mathrm{~nm}$ ultraviolet light. Journal of Environmental Engineering \& Science 6, 179-180.

Gao, L., Minakata, D., Wei, Z., Spinney, R., Dionysiou, D. D., Tang, C. J., Chai, L., and Xiao, R. (2019). Mechanistic Study on the Role of Soluble Microbial Products in Sulfate Radical-Mediated Degradation of Pharmaceuticals. Environ Sci Technol 53, 342-353.

Ghauch, A., and Tuqan, A. M. (2012). Oxidation of bisoprolol in heated persulfate/H2O systems: Kinetics and products. Chemical Engineering Journal 183, 162-171.

Giannakis, S., Lin, K.-Y. A., and Ghanbari, F. (2021). A review of the recent advances on the treatment of industrial wastewaters by Sulfate Radical-based Advanced Oxidation Processes (SR-AOPs). Chemical Engineering Journal 406.

Guo, K., Wu, Z., Shang, C., Yao, B., Hou, S., Yang, X., Song, W., and Fang, J. (2017). Radical Chemistry and Structural Relationships of PPCP Degradation by UV/Chlorine Treatment in Simulated Drinking Water. Environmental Science \& Technology 51, 10431. 
Guo, K., Wu, Z., Yan, S., Yao, B., Song, W., Hua, Z., Zhang, X., Kong, X., Li, X., and Fang, J. (2018). Comparison of the UV/chlorine and UV/H2O2 processes in the degradation of PPCPs in simulated drinking water and wastewater: Kinetics, radical mechanism and energy requirements. Water Res 147, 184-194.

He, D. Q., Zhang, Y. J., Pei, D. N., Huang, G. X., Liu, C., Li, J., and Yu, H. Q. (2020). Degradation of benzoic acid in an advanced oxidation process: The effects of reducing agents. J Hazard Mater 382, 121090.

Herrmann, H., Ervens, B., Nowacki, P., Wolke, R., and Zellner, R. (1999). A chemical aqueous phase radical mechanism for tropospheric chemistry. Chemosphere 41, 633-634.

Hisaindee, S., Meetani, M. A., and Rauf, M. A. (2013). Application of LC-MS to the analysis of advanced oxidation process (AOP) degradation of dye products and reaction mechanisms. Trends in Analytical Chemistry 49, 31-44.

Hori, H., Yamamoto, A., Hayakawa, E., Taniyasu, S., Yamashita, N., Kutsuna, S., Kiatagawa, H., and Arakawa, R. (2005). Efficient decomposition of environmentally persistent perfluorocarboxylic acids by use of persulfate as a photochemical oxidant. Environmental Science \& Technology 39, 2383-2388.

Keen, O. S., Mckay, G., Mezyk, S. P., Linden, K. G., and Rosario-Ortiz, F. L. (2014). Identifying the factors that influence the reactivity of effluent organic matter with hydroxyl radicals. Water Research 50, 408-419.

Khan, N. E., and Adewuyi, Y. G. (2010). Absorption and Oxidation of Nitric Oxide (NO) by Aqueous Solutions of Sodium Persulfate in a Bubble Column Reactor. Industrial \& Engineering Chemistry Research 49, 8749-8760.

Kwon, M., Kim, S., Yoon, Y., Jung, Y., Hwang, T.-M., Lee, J., and Kang, J.-W. (2015). Comparative evaluation of ibuprofen removal by UV/H2O2 and UV/S2O82- processes for wastewater treatment. Chemical Engineering Journal 269, 379-390.

Lee, D., Kwon, M., Ahn, Y. T., Jung, Y., Nam, S. N., Choi, I. H., and Kang, J. W. (2018). Characteristics of intracellular algogenic organic matter and its reactivity with hydroxyl radicals. Water Research 144, 13.

Mahdi-Ahmed, M., and Chiron, S. (2014). Ciprofloxacin oxidation by UV-C activated peroxymonosulfate in wastewater. Journal of Hazardous Materials 265, 41-46.

Matta, R., Tlili, S., Chiron, S., and Barbati, S. (2011). Removal of carbamazepine from urban wastewater by sulfate radical oxidation. Environmental Chemistry Letters 9, 347-353.

Milh, H., Yu, X., Cabooter, D., and Dewil, R. (2021). Degradation of ciprofloxacin using UV-based advanced removal processes: Comparison of persulfate-based advanced oxidation and sulfite-based advanced reduction processes. Sci Total Environ 764, 144510.

Nagarnaik, P. M., and Boulanger, B. (2011). Advanced oxidation of alkylphenol ethoxylates in aqueous systems. Chemosphere 85, 854-860.

Osburn, C. L., Retamal, L., and Vincent, W. F. (2009). Photoreactivity of chromophoric dissolved organic matter transported by the Mackenzie River to the Beaufort Sea. Marine Chemistry 115, 10-20.

Reisz, Erika, Schmidt, Winfried, Schuchmann, HeinzPeter, Sonntag, and Von, C. (2003). Photolysis of ozone in aqueous solutions in the presence of tertiary butanol. Environmental Science \& Technology 37, 1941-1948.

Rosal, R., Rodríguez, A., Perdigónmelón, J. A., Petre, A., Garcíacalvo, E., Gómez, M. J., Agüera, A., and Fernándezalba, A. R. (2010). Occurrence of emerging pollutants in urban wastewater and their removal through biological treatment followed by ozonation. Water Research 44, 578-588.

Rosenfeld, E. J., and Linden, K. G. (2007). The ROH,UV concept to characterize and the model uv/H202 process in natural waters. Environmental Science \& Technology 41, 2548-53.

Singla, R., Ashokkumar, M., and Grieser, F. (2004). The mechanism of the sonochemical degradation of benzoic acid in aqueous solutions. Research on Chemical Intermediates 30.

Taoufik, N., Boumya, W., Achak, M., Sillanpaa, M., and Barka, N. (2021). Comparative overview of advanced oxidation processes and biological approaches for the removal pharmaceuticals. J Environ Manage 288, 112404.

Vigneswaran, S. (2006). Effluent Organic Matter (EfOM) in Wastewater: Constituents, Effects, and Treatment. Critical Reviews in Environmental Science \& Technology 36, 327-374.

Watts, M. J., and Linden, K. G. (2007). Chlorine photolysis and subsequent OH radical production during UV treatment of chlorinated water. Water Research 41, 2871-2878. 
Wols, B. A., and Hofman-Caris, C. H. (2012). Review of photochemical reaction constants of organic micropollutants required for UV advanced oxidation processes in water. Water Research 46, 2815-2827.

Yang, Y., Pignatello, J. J., Ma, J., and Mitch, W. A. (2014). Comparison of halide impacts on the efficiency of contaminant degradation by sulfate and hydroxyl radical-based advanced oxidation processes (AOPs). Environmental Science \& Technology 48, 2344.

Yang, Y., Pignatello, J. J., Ma, J., and Mitch, W. A. (2016). Effect of matrix components on $\mathrm{UV} / \mathrm{H} 2 \mathrm{O} 2$ and UV/S $2 \mathrm{O} 82$ - advanced oxidation processes for trace organic degradation in reverse osmosis brines from municipal wastewater reuse facilities. Water Research 89, 192-200.

Ying-Hong, G., Jun, M., Xu-Chun, L., Jing-Yun, F., and Li-Wei, C. (2011a). Influence of $\mathrm{pH}$ on the formation of sulfate and hydroxyl radicals in the UV/peroxymonosulfate system. Environmental science \& technology $\mathbf{4 5}$.

Ying-Hong, G., Jun, M., Xu-Chun, L., Jing-Yun, F., and Li-Wei, C. (2011b). Influence of $\mathrm{pH}$ on the formation of sulfate and hydroxyl radicals in the UV/peroxymonosulfate system. Environmental Science \& Technology 45, 9308.

Yuan, F., Hu, C., Hu, X., Wei, D., Chen, Y., and Qu, J. (2011). Photodegradation and toxicity changes of antibiotics in UV and UV/H2O2 process. Journal of Hazardous Materials 185, 1256-1263.

Zhou, L., Sleiman, M., Ferronato, C., Chovelon, J.-M., and Richard, C. (2017). Reactivity of sulfate radicals with natural organic matters. Environmental Chemistry Letters 15, 733-737.

Zhou, L., Zheng, W., Ji, Y., Zhang, J., Zeng, C., Zhang, Y., Wang, Q., and Yang, X. (2013). Ferrous-activated persulfate oxidation of arsenic(III) and diuron in aquatic system. Journal of Hazardous Materials 263, 422-430. 
Figures
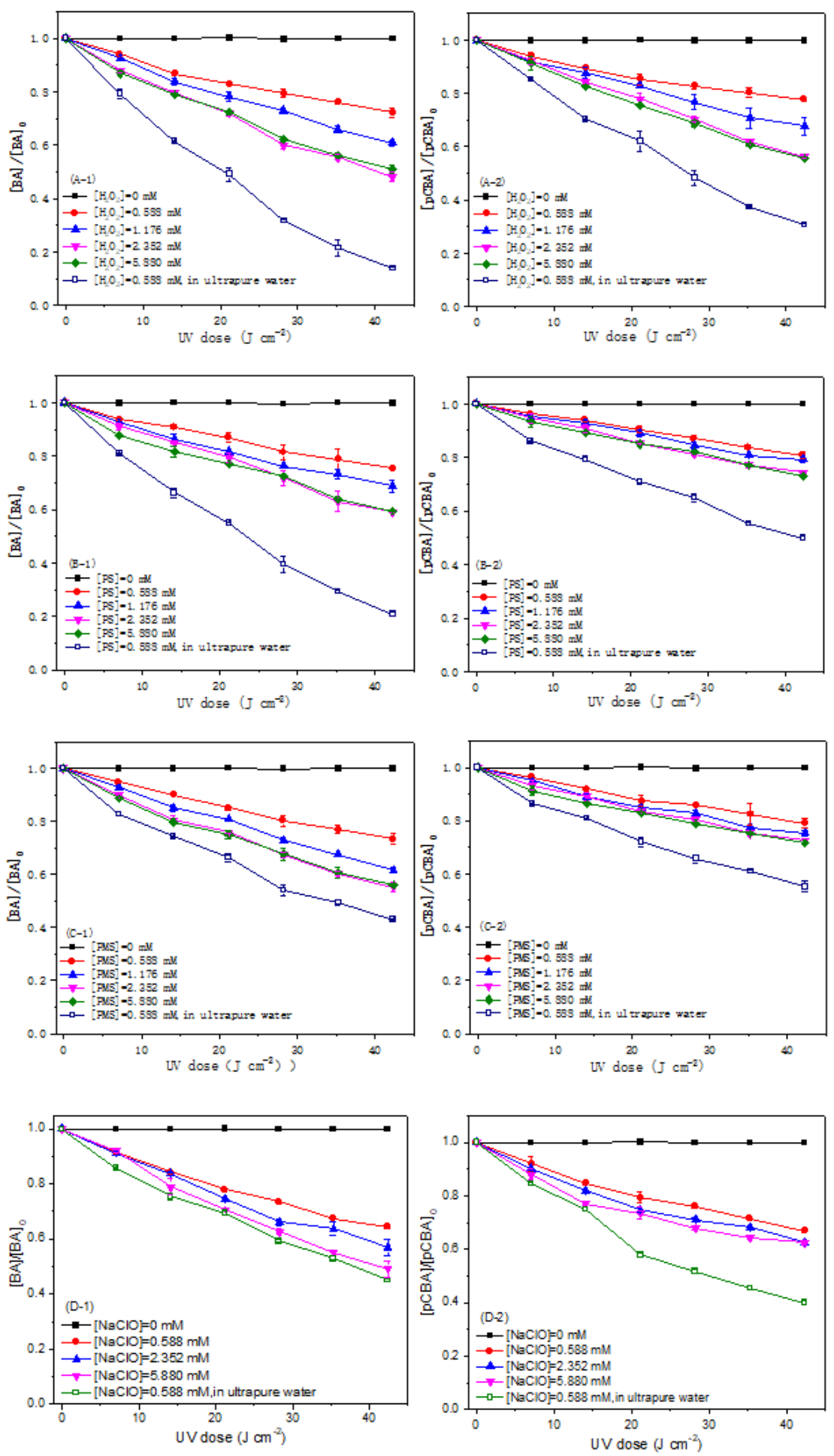

Figure 1

Degradation profile of probes (BA and p-CBA) in UV-based AOP: (A) UV/ H2O2, (B) UV/PS, (C) UV/PMS, (D) UV/Cl; 1-BA, 2-pCBA. 

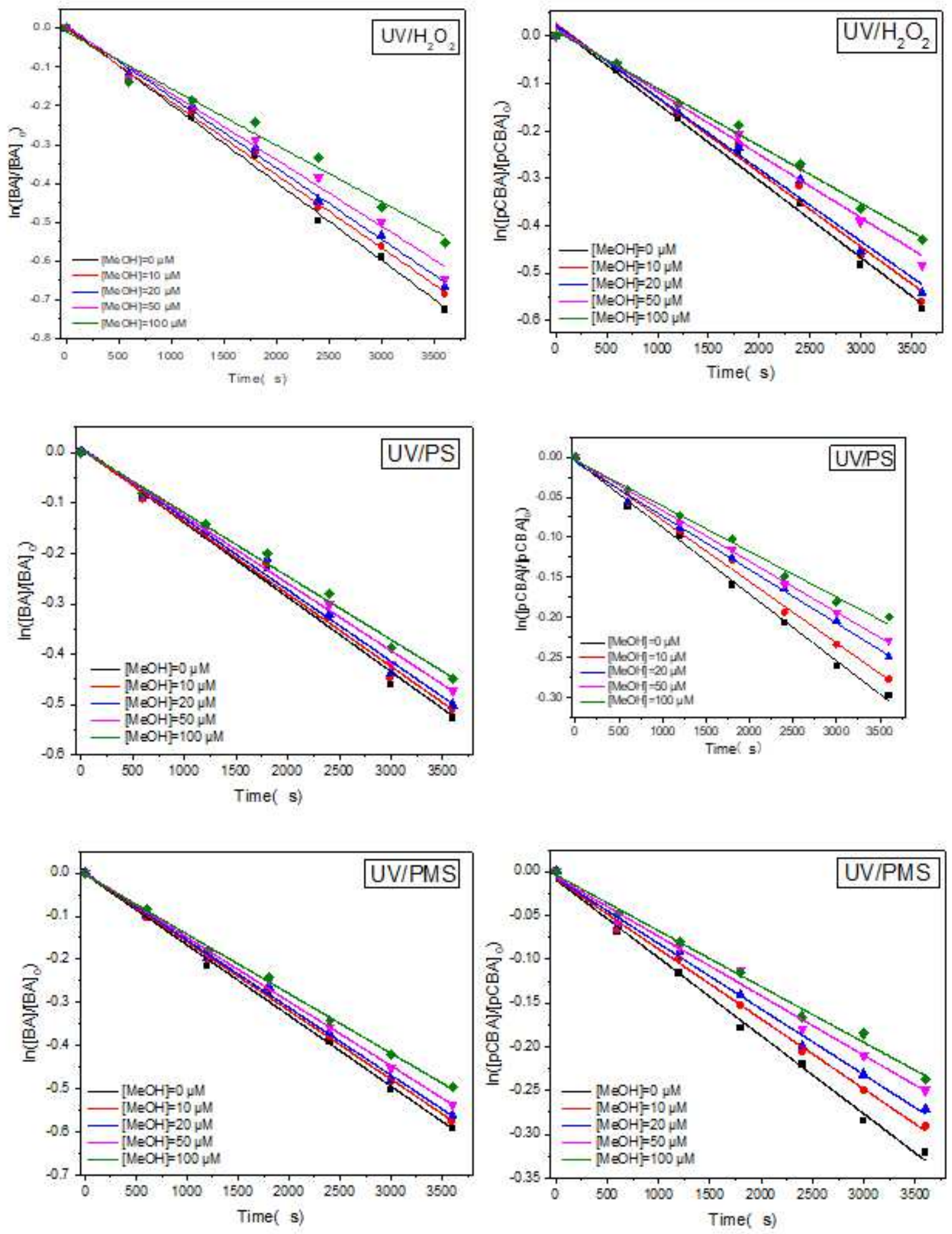

\section{Figure 2}

Pseudo primary degradation of added $\mathrm{MeOH}$ in EfOM (includes $\mathrm{BA}$ and $\mathrm{p}-\mathrm{CBA}$ ) Reaction conditions $\mathbb{\mathrm { B }}[\mathrm{BA}]$ $0=[p-C B A] 0=1.0 \mu \mathrm{M} \otimes[\mathrm{PS}] 0=[\mathrm{PMS}] 0=[\mathrm{H} 2 \mathrm{O} 2] 0=2.352 \mathrm{mM} \otimes[\mathrm{MeOH}] 0=0,10 \rrbracket 20 \rrbracket 50 \otimes 100 \mathrm{Mm}$ 

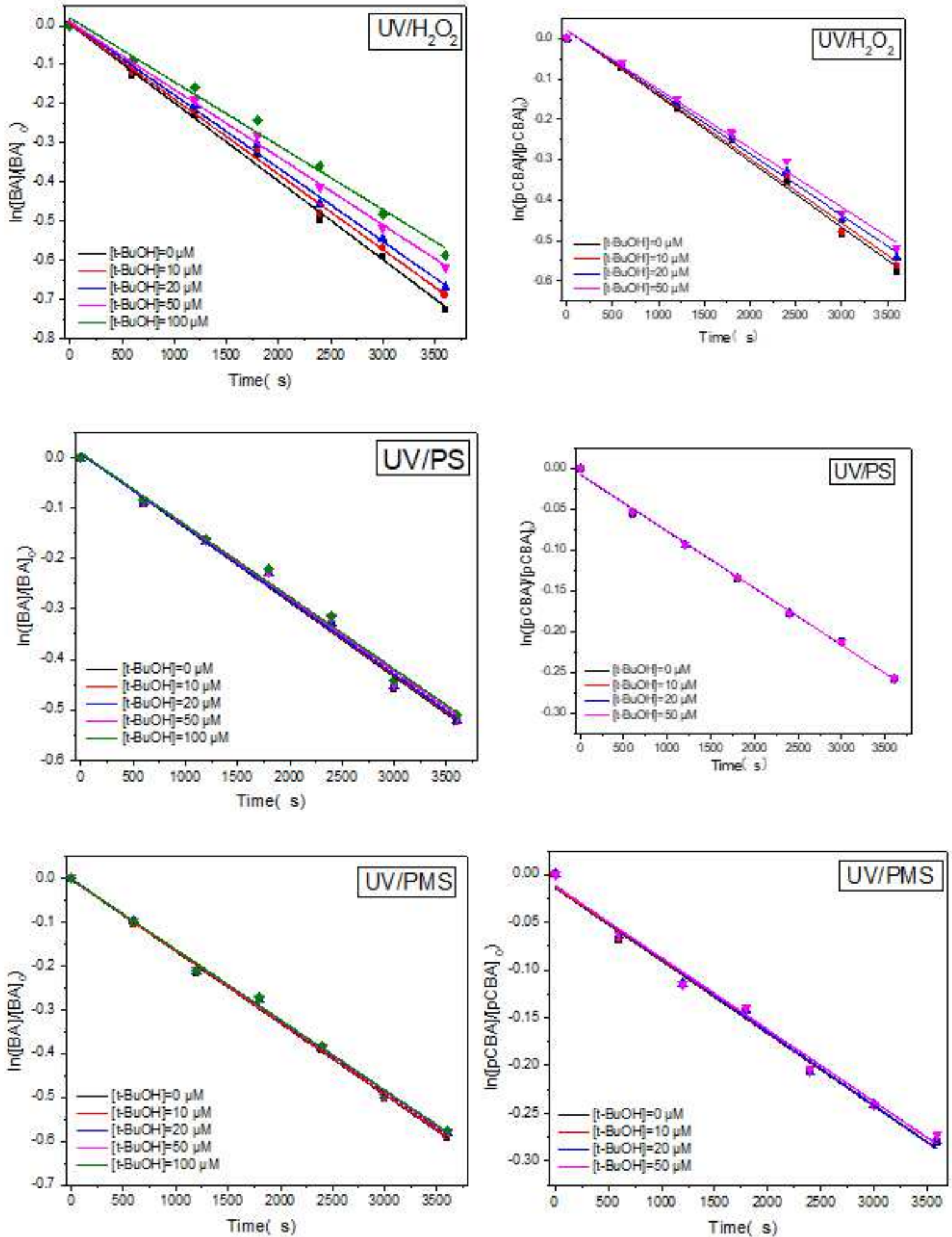

Figure 3

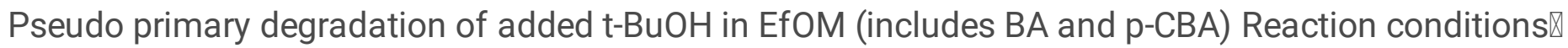
$[B A] 0=[p-C B A] 0=1.0 \mu \mathrm{M} \otimes[P S] 0=[P M S] 0=[H 2 O 2] 0=2.352 \mathrm{mM}[t-B u O H] 0=0,10 \otimes 20 \otimes 50 \otimes 100 \mu \mathrm{M}$ 

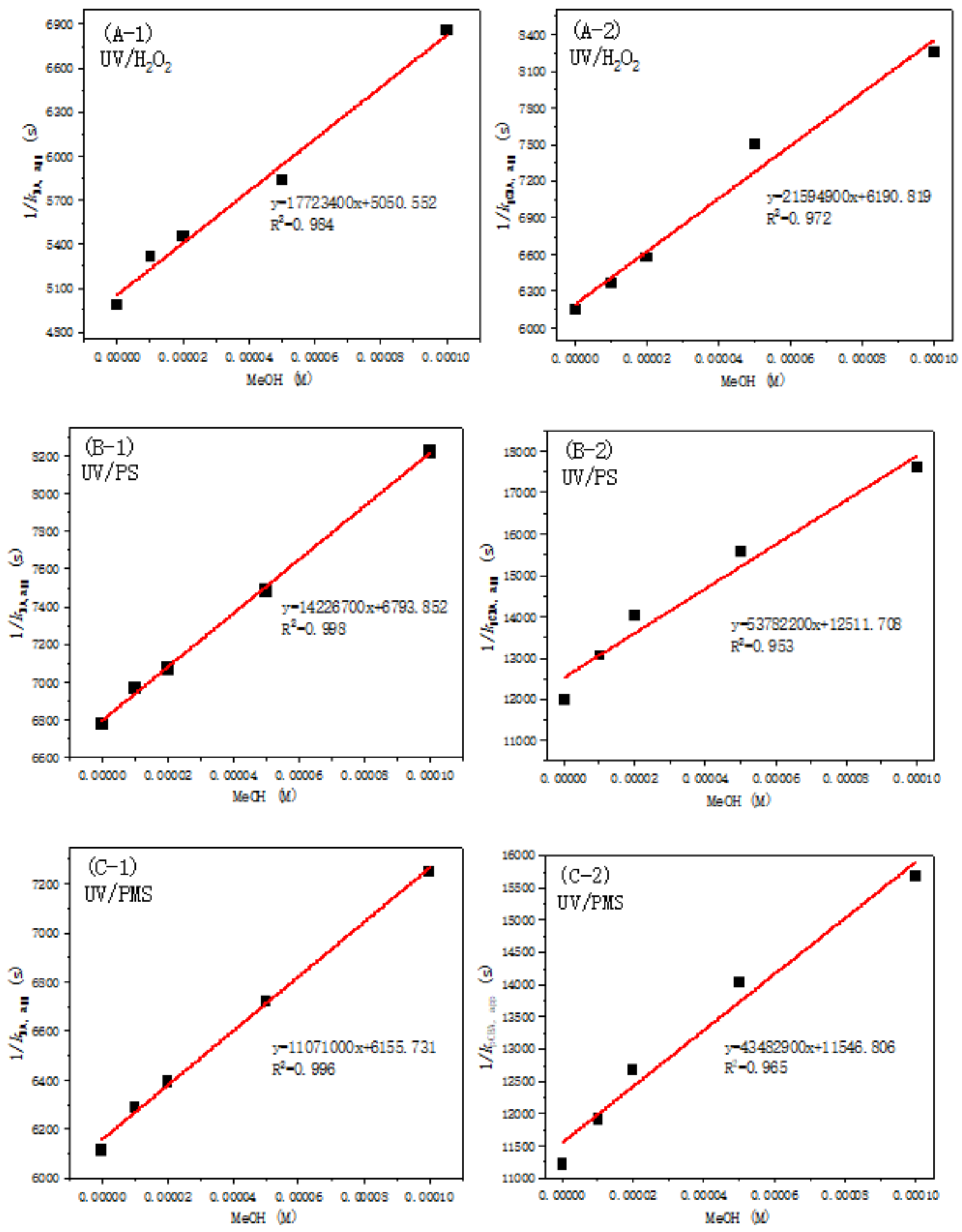

\section{Figure 4}

Reciprocal of the apparent rate constants for BA and pCBA vs. MeOH concentrations: (a) UV/H2O2 system; (b) UV/PS system; (c) UV/PMS system Reaction conditions: [BA or p-CBA] $0=1.0 \mu \mathrm{M}$, [oxidant] $0=2.352 \mathrm{mM}, \mathrm{E} 0=1.217 \mathrm{~mW} \mathrm{~cm}-2$, solution $\mathrm{pH}=7.9$ 

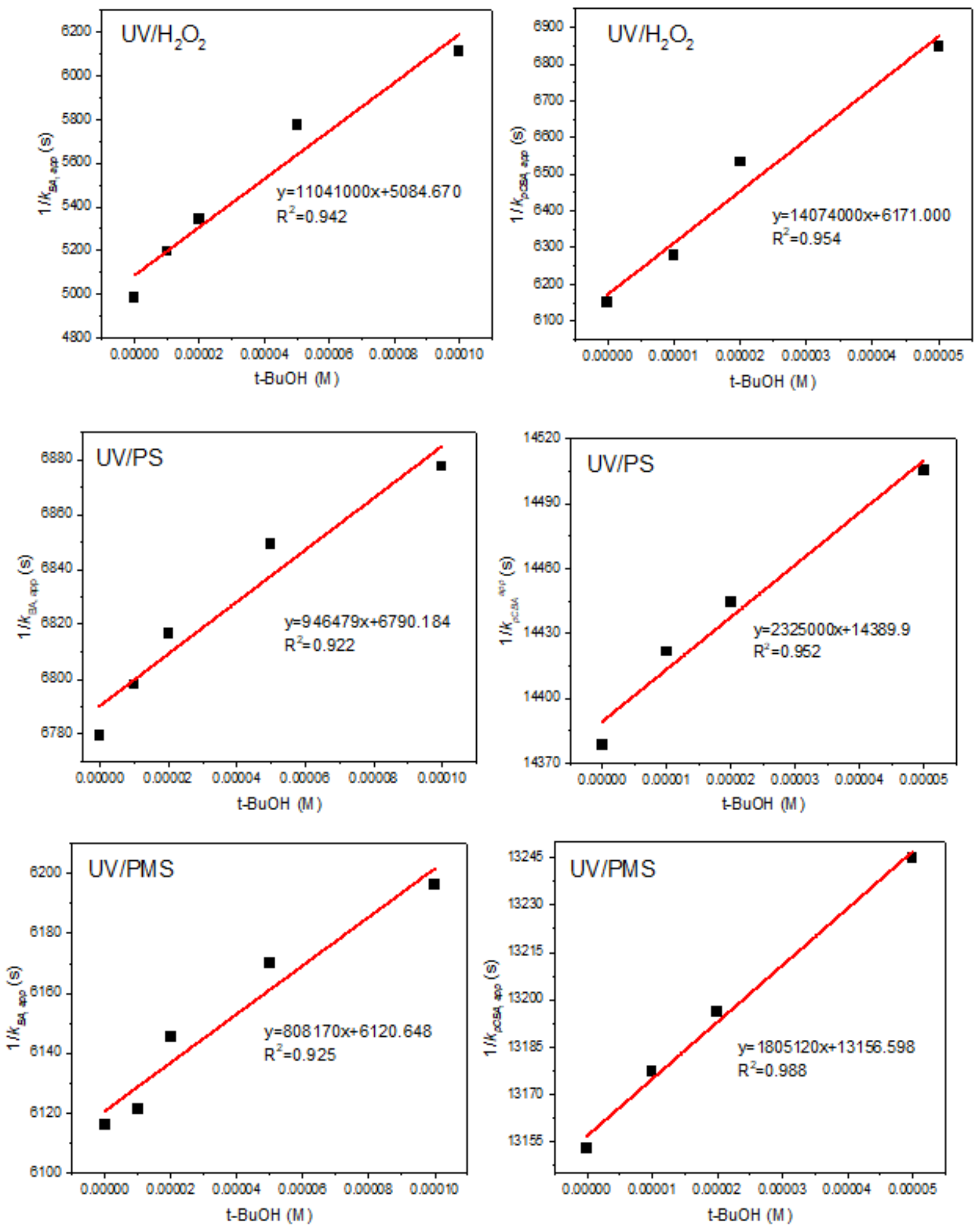

\section{Figure 5}

Competitive dynamics of $\mathrm{BA}$ and $\mathrm{p}-\mathrm{CBA}$ at different tert-butanol concentrations Reaction conditions $\mathbb{\mathrm { B }}[\mathrm{BA}] 0$ $=[\mathrm{p}-\mathrm{CBA}] 0=1.0 \mu \mathrm{M} \otimes[\mathrm{PS}] 0=[\mathrm{PMS}] 0=[\mathrm{H} 2 \mathrm{O} 2] 0=2.352 \mathrm{mM}[\mathrm{t}-\mathrm{BuOH}] 0=0 \rrbracket 10 \rrbracket 20 \rrbracket 50 \rrbracket 100 \mu \mathrm{M}$ 


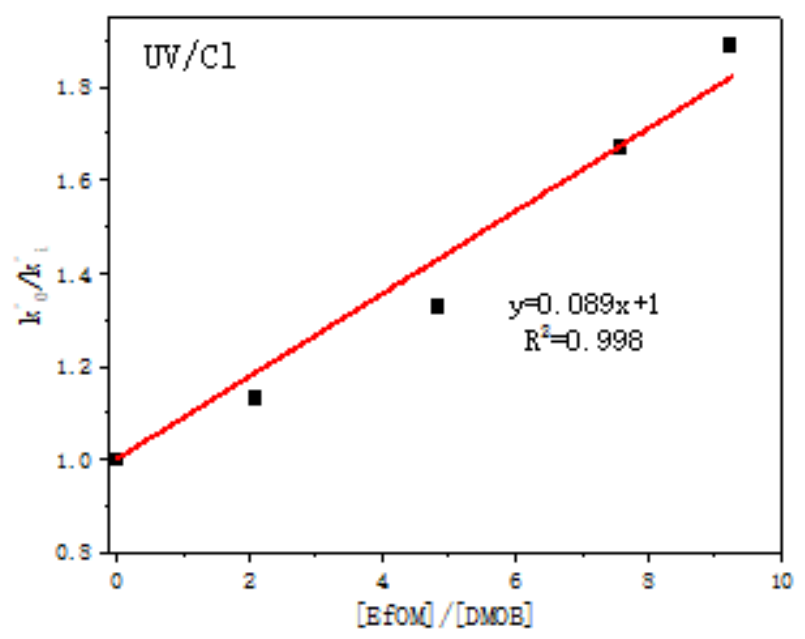

Figure 6

Competition kinetic plot for $\mathrm{ClO}$ - reaction with EfOM using 1,4-dimethoxybenzene (DMOB) as a reference compound. Reaction conditions: [chlorine]0 $=2.353 \mathrm{mM},[\mathrm{DMOB}] 0=5.0 \mu \mathrm{M},[\mathrm{EfOM}] 0=0,1444,3344,5244$, $6384 \mu \mathrm{L} \mathrm{L-1}$ 

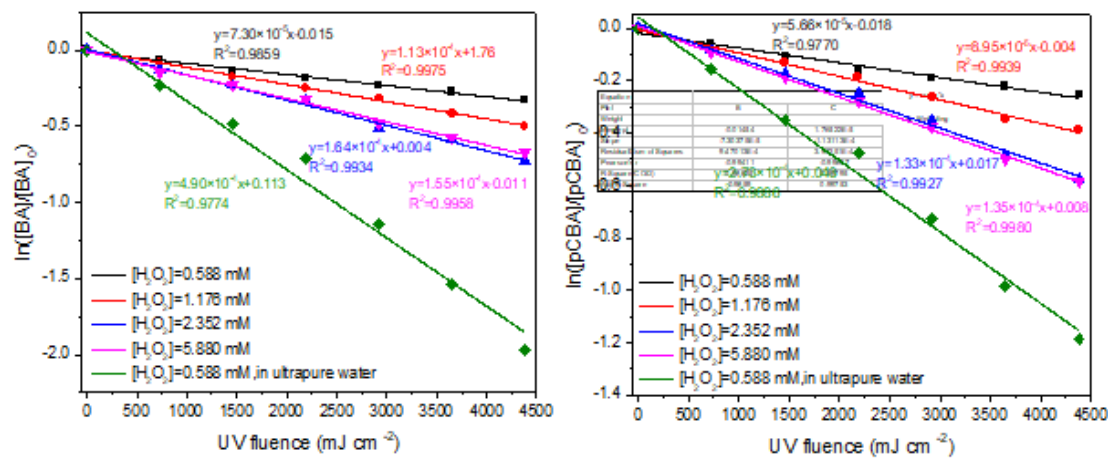

UV fluence $\left(\mathrm{mJ} \mathrm{cm}{ }^{-2}\right)$
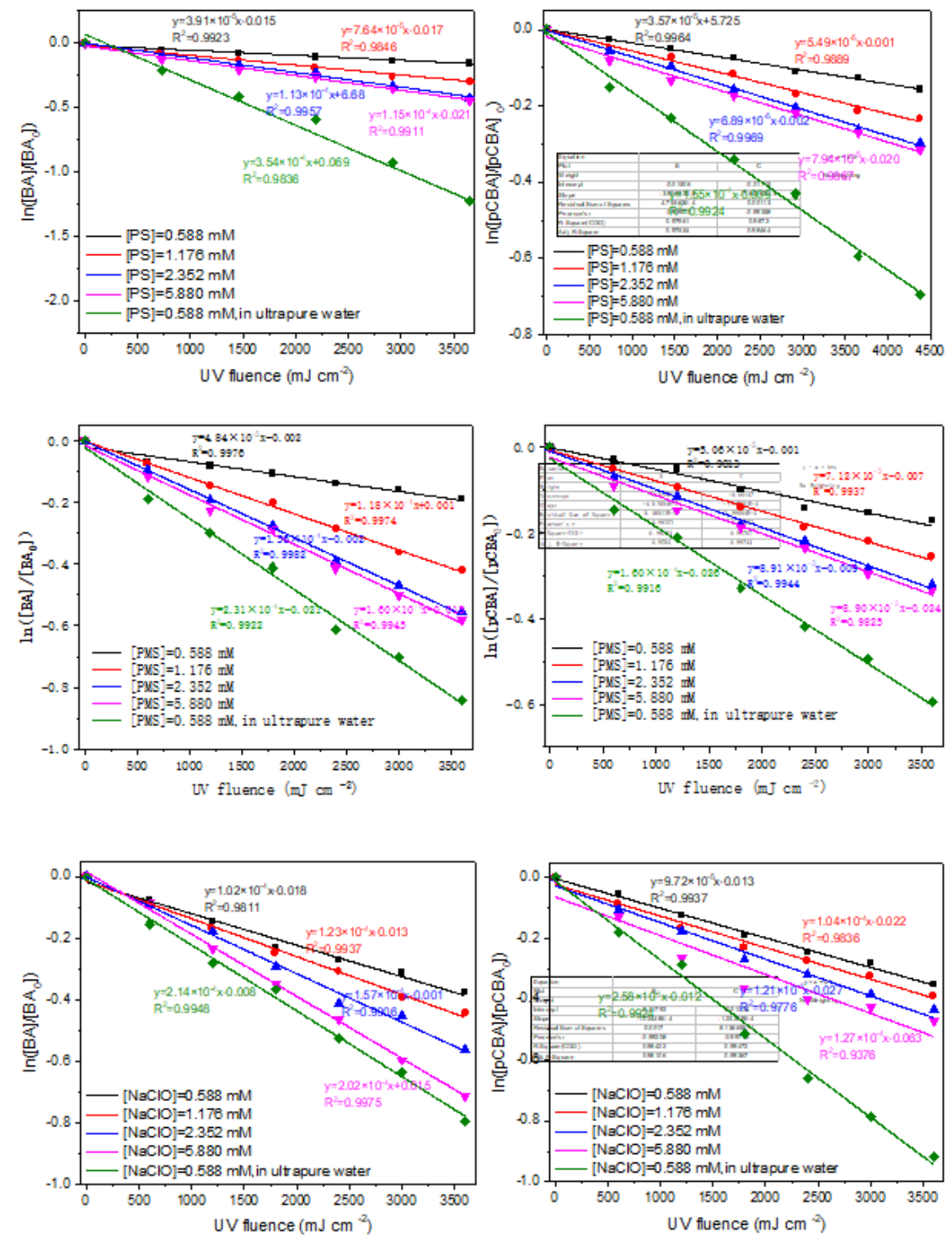

Figure 7

Pseudo-first-order degradation of BA (or $\mathrm{p}-\mathrm{CBA}$ ) by different oxidant concentrations in EfOM and ultrapure water Reaction conditions: [BA or $\mathrm{p}-\mathrm{CBA}]=1.0 \mu \mathrm{M}, \mathrm{E} 0=1.217 \mathrm{~mW} \mathrm{~cm}-2$, solution $\mathrm{pH}=7.9$ 
This is a list of supplementary files associated with this preprint. Click to download.

- SupplementaryMaterial.docx 